Available online at: http://proceeding.rsfpress.com/index.php/ic-smart/index

Proceeding on International Conference of Science Management Art Research Technology

(IC-SMART)

Volume 1 Number 1 (2020): 78-88

\title{
Indonesian Shipping Sustainable Development Law Approach Through Cabotage Principle
}

\author{
Elfrida Ratnawati \\ Faculty of Law, Universitas Trisakti, Jakarta \\ E-mail address elfrida.r@trisakti.ac.id
}

\begin{abstract}
The national shipping industry plays an important role in the maritime sector because if its development performance can be supported and well-managed, the industry would increase Indonesian foreign exchange that would lead to achievements in economic development for the prosperity of Indonesian people. To achieve these goals, the cabotage principle with a legal basis of Law Number 17 the Year 2008 and Presidential Instruction Number 5 the Year 2005 on National Shipping Industry Empowerment, must be applied consequently by formulating necessary policies and steps. This paper will discuss the problems of cabotage application in the Indonesian shipping industry and the positive and negative impacts of the principle. The utilized research method is a normative method supported by secondary and primary data, which is further descriptively analyzed. The result of this research reveals that the application of the cabotage principle is regarded as a national economic driver in relation to the sea transportation sector because it provides a high opportunity for domestic ships to transport people and goods all over Indonesia. With the application of the cabotage principle, it is hoped that the Indonesian shipping industry can be able to act as the dominator in Indonesia, and national shipping industry development will consistently be improved on sustainable and continuous manners and bring a positive impact on the national economy and the prosperity of Indonesian people.
\end{abstract}

Keywords: Law, Development, Shipping, Cabotage

\section{INTRODUCTION}

This is an open access article under the CC-BY-NC license

As an archipelago country that consists of thousands of islands and is supported by vast sea territory, Indonesia is a country with abundant natural resources. Indonesia possesses an area which is divided into 1.9 million $\mathrm{km} 2$ of land and 5.9 million $\mathrm{km} 2$ of the sea. It shows that the area of the Indonesian sea is three times larger than the land area. To reach one and another, Indonesian often requires sea transportation, for example, a ship, which is important to connect one island and another and also to distribute goods and services all over Indonesia, which is seen as a more effective and efficient way than other types of transportation. However, with the high marine potential as an invaluable resource, Indonesia is still unable to optimally utilize its potential (Sofiyanti \& Suartini, 2016)

Sea transportation, especially ships, is highly required to link one island or region with another in Indonesia. Ships are needed as a means of sea transportation, which is used to transport passengers 
and goods, as well as to conduct offshore activities in Indonesian water territory. Ships have a very important function to support numerous activities in the Indonesian sea and the advances of the Indonesian economy.

Because of that, the Indonesian shipping industry must be supported. Based on the collected data, in the last few years, the ships utilized in these activities are mostly owned by foreign companies (Biro Komunikasi dan Informasi Publik, 2016). What is the cause? The cause of the high frequency of foreign ships in Indonesia is that the inability of the domestic shipping industry to buy their own ship to be utilized in their shipping activities and some of them prefer to rent foreign ships even though they have the ability to buy their own ship. Because of that, these industrials are indeliberately caused enormous losses for the country.

There are so many challenges faced by the government to improve the Indonesian shipping industry. For example, the application of the monetary policy on the shipping industry where the applied interest rate is higher than the profit made the application of fiscal policy, which states that valueadded tax must be applied to the shipping industry and domestic fuel consumption policy. If we conclude the situation, there are different types of treatments of shipping industry policies in Indonesia than in other countries (Hadi, 2019). While in fact, the Indonesian shipping industry plays an important role in improving other related industries (Wijaya, 2019). This challenge is only a small part of shipping industry difficulties besides port cost policy and unorganized ship size and type registrations by the government.

Besides the difficulties above, another threat comes from the existence of domestic ships in the industry. Indonesia is still categorized as guests in the domestic shipping industry because the companies tend to utilize foreign ships to transport goods and services to certain areas in Indonesia. Because of that, apart from the lack of ships with high carrying capacity, some of the Indonesian ports are unable to accommodate large ships. Indonesia's Balance of Payment (IBP) regularly experiences deficits, which is caused by high losses and low income in the shipping sector. On the other hand, Indonesia is still highly dependent on foreign shipping companies with a frequency of 95 percent to conduct international export-import activities, and domestic market share for the shipping industry owned by foreign companies is at 40 percent. Ministry of Finance has created a study on the foreign shipping industry and reveals that they possess 78 ships with 94 carrying capacity, used on 90 of export and import payloads. Even though domestic shipping is now 100 percent carried out by domestic armada, the ships are still produced and bought from foreign companies, either through charter or leasing facilities.

In the period of 2005-2015, the number of national armada experiences significant improvement. In 2005 Indonesian armada consisted of only 6,041 ships, which improved to 16,574 ships in 2015. However, most Indonesian shipping armadas only consist of low carrying capacity vessels and unable to compete with foreign ships (Data Boks, 2017).

\section{Table 1}

\begin{tabular}{|c|c|c|}
\hline NO & YEAR & NUMBER OF SHIPS \\
\hline 1 & 2005 & 6,041 \\
\hline 2 & 2008 & 8,165 \\
\hline 3 & 2011 & 10,902 \\
\hline 4 & 2015 & 16,574 \\
\hline
\end{tabular}

Source: Bank Indonesia, 2017 
This research is based on the problems of the national shipping industry, which is dominated by foreign ships (CNBC Indonesia, 2018). The literature review result of several researchers reveals that the implementation of the cabotage principle brings a great influence on the national shipping industry, which proves that as long as this principle is implemented, the national shipping industry will keep on improving (Indonesia Maritime Blog Informations, 2019). The number of national armada and ships will keep on improving so that the national loading activities can be dominated by national shipping companies (Mahlisan, 2010). Besides that, the unemployment will decrease along with the improvement of the national shipping industry, because there is a regulation that compels domestic ships to be manned by an Indonesian citizen.

The issuance of Law Number 17, the Year 2008, is the birth of the cabotage principle in Indonesia. The application of the cabotage principle is contained in Law Number 17 the Year 2008 verse 8;

a. Domestic shipping activities must be conducted by a national shipping company by utilizing Indonesia flagged ships manned by Indonesian citizen crew members.

b. Foreign ships are forbidden to carry passengers and/or goods between islands or ports in the Indonesian sea.

With the application of this principle, the Indonesian government compels domestic shipping companies to own Indonesia flagged ships/to own their own ships and to employ Indonesian citizen crews.

The aim of the government with the implementation of the cabotage principle is to drive Indonesian shipping companies as the dominator in their own sea (Aprilianto, Hakim, \& Hayat, 2014). Besides that, with the implementation of this principle, the Indonesian shipping industry is expected to be better and more conducive, and to prevent foreign companies from dominating the domestic shipping industry. However, the implementation of this principle is not enough if it is not optimally implemented. Because of that, this paper will answer the problems of cabotage principle implementation in the Indonesian shipping industry, along with the positive and negative impact of the principle implementation. Implementation is one of the most important parts of a policy, where an optimum role either from the government and other stakeholders is highly required (Nusantara Maritime News, 2015).

If the policy is not well implemented, the policy will not bring a positive impact. Because of that, we will deeply discuss Indonesian Shipping Sustainable Development Law Approach through Cabotage Principle, so it would provide a significant impact on the growth and development of Indonesian shipping industry.

\section{LITERATURE REVIEW}

Hasbullah Masyur, on his paper titled National Shipyard Strengthening Strategy to Improve National Domestic Shipping Armada Effectivity and Efficiency in 2030, mentioned that there is an urgency of national normative domestic industry improvement as a solution to enhance national shipping industry as a transportation facility to carry goods and passengers between islands. This goods and services transportation is a part of a government program aimed to improve the national shipping industry. The research-based paper is used as a guide to improve shipyard capacity to produce new ships, including reparation/docking. The result of the research revealed that ship production is highly needed by conducting inventory on shipyard condition and operational capacity to build and repair ships according to the existing timetable (Hasbullah, 2016).

Rivo Bagus Saputra wrote a paper titled Cabotage Principle on Indonesian Shipping Law. This paper emphasizes an understanding that the cabotage principle does not violate freedom of navigation 
Proceeding on International Conference of Science Management Art Research Technology (IC-SMART), Vol. 1 (1), 78-88

Indonesian Shipping Sustainable Development Law Approach Through Cabotage Principle

Elfrida Ratnawati

because the freedom principle is not absolute. It is up to a country to limit the activity based on their sovereignty to implement cabotage on their own maritime territory as regulated in international law (Saputra, 2016).

Asnawi and M Iqbal, in their paper titled The Implication of Cabotage Principle Implementation on National Shipping against The Existence of Indonesian Shipping Companies on WTO Free Trading Framework, mentioned that the maritime sector is a highly strategic sector for Indonesia as the largest archipelago in the world because the sector has provided immense contributions on national development success in Indonesia. The contributions are basic needs provision, the improvement of people's earnings, working opportunity, foreign exchange, and local development. Based on this paper, it was concluded that the sea is basically possessed advantages for future national development. The implementation of the cabotage principle is contained in Law Number 17 the Year 2008 on Shipping as an urgent aspect on national development and marine shipping independency. The existence of the cabotage principle is a manner of national sea transportation in domestic shipping activities. Because of that, it is forbidden for foreign shipping companies to conduct their activities inside Indonesian sea territory (between islands/ports). The implementation of this principle also possesses negative potential such as disruption on offshore and oil and gas mining activities if Indonesian national shipping companies do not prepare themselves to be able to provide services for these activities, which would further produce a high impact on the Indonesian national economy. Operation in this field would also produce a potential for foreign exchange loss when the activities are not practiced by domestic stakeholders. Because of that, government support to create funding facilities for these activities is highly expected by national shipping companies. The high boat price and low production quantity make it hard for these companies to acquire the required ships for their activities (Asnawi \& Iqbal, 2012).

Anton Pangihutan, Muhammad Thamrin, and Asep Suparman, wrote a paper titled The Quality of Shipping Agency Service and International Communication on Shipping Industry, analyze the shipping agents' services quality, which is a highly important aspect of customer experience (Pangihutan, Thamrin, \& Suparman, 2016).

F. Isdiana and J. Aminata wrote a paper on Indonesian Export Analysis with APEC Members through Sea Transportation Mode. This paper analyzes Indonesian export performance with APEC members by utilizing sea transportation mode. The aim of this research is to review the condition of transportation, especially Indonesian infrastructure as a support to international trading activity, and to analyze the factors that influence Indonesian export volume to APEC country members by utilizing sea transportation mode, with a gravitational model approach (Aminata \& Isdiana, 2019)..

\section{RESEARCH METHODOLOGY}

The method utilized in this research is a normative approach, which focuses on the applicable norms and regulations regarding cabotage principle implementation in the Indonesian shipping industry, which descriptively analyzed by using a qualitative approach. This research analyzes the implementation of the cabotage principle in Indonesian shipping policy, the supporting and inhibiting factors of the cabotage principle, and the impact of cabotage principle implementation on the Indonesian shipping industry. The research was conducted in DKI Jakarta through the Indonesian Directorate General of Sea Transportation of Ministry of Transportation and Indonesian National Ship Owners Association or INSA sites.. 


\section{FINDING AND DISCUSSION}

IV.1. Countries that Implement Cabotage Principle

Besides Indonesia, European Union countries have also implemented the cabotage principle, along with its supporting regulations contained in Council Regulation Number 3577 the Year 1992. This regulation states that ships that sail on European Union territory must belong and registered to one of the European Union countries. The result obtained by the European Union after the implementation of the cabotage principle is the improvement of national shipping quality in European Union countries and the total control of the world's sea transportation industry by European Union countries.

The United States of America has also implemented cabotage, which contained in the Jones Act as an amendment of Section 27 of the Merchant Marine Act 1920. This regulation states that every logos transported between American ports must be carried by ships owned, manufactured, and manned by an American citizen, and documented under American Law. This regulation has also proven to be able to improve the American national shipping sector while also empower its national ships as defense and security components.

Indonesia implements regulations of cabotage principle as regulated in Law Number 21 the Year 1992 regarding Shipping and Government Regulation Number 51 the Year 2002 regarding Shipping. The content of these rules regulates every ship sailed in Indonesian territory must utilize Indonesian flagged ships while also act as national defense and security components. However, these regulations are not implemented well because Indonesia was focused on non-oil and gas export sectors that require foreign ships in its operational activities.

However, the cabotage principle is further enhanced by the issuance of Law Number 17 the Year 2008 on Shipping after before, strengthened with a policy issued by the government, which is President Instruction Number 5 the Year 2005 on National Shipping Industry Empowerment. However, the implementation of the cabotage principle by related ministries is yet to reach maximum capacity and firmness because of the lack of coordination and support on the required facilities and infrastructures (Saputra, 2016).

Cabotage principle is further regulated in Government Regulation Number 22 the Year 2011, as an amendment of Government Regulation Number 20 the Year 2010 on Sea and Water Transportations. This regulation is a response against inhibiting factors caused by Law Number 17 the Year 2008 on Shipping, which should be revised by the government but unable to reach consensus to revise it (Bonaparte, 2017).

In Government Regulation Number 22 the Year 2011 XIII A Section 206A Verse (1) and (2), it is stated that "foreign ship can conduct other activities besides carrying a passenger and/or goods in Indonesian domestic water, as long as similar flagged Indonesian ship is not available or not adequate, and permitted by the Minister." This regulation then enhanced further in Ministry of Transportation Regulation Number PM 48 Year 2011.

There is a dilemma from the two regulations mentioned above. Government Regulation Number 22 the Year 2011 manages to facilitate several shipping conditions in Indonesia, but also produce law uncertainty if connected with cabotage principle implementation in Indonesian waters. Law Number 17 the Year 2008 on Shipping states that the implementation of the principle is started from May 7th, 2011, but Government Regulation Number 22 the Year 2011 states that foreign ships are permitted to operate until 2015, even several foreign ships are still allowed to operate until the end of 2017.

\subsection{The Implementation of Cabotage Principle Regulations}


Proceeding on International Conference of Science Management Art Research Technology (IC-SMART), Vol. 1 (1), 78-88

Indonesian Shipping Sustainable Development Law Approach Through Cabotage Principle

Elfrida Ratnawati

Cabotage principle is regulated in Chapter on Shipping Transportation Law Number 22 Year 2011. By practice, the shipping regulation is equipped with specific Government Regulation, which focuses on domestic transportation activities. The regulation arranged every goods/service transportation activity and other types of activities related to oil and gas and offshore activities. Along the time, this Government Regulation experiences changes because of the unreadiness of national shipping armada to serve oil and gas and offshore activities.

Based on that, for oil and gas and offshore activities, foreign transportation ships are still allowed to operate, although there is a strict regulation in the shape of the Ministry of Transportation Regulation and a restriction of the period until 2015. In a long period of time, national transportation is expected to be able and ready to serve oil and gas mining and offshore activities.

The implementation of the cabotage principle on national shipping and transportation is highly affecting the increase of armada number and available market share. Because of that, national tax earning and the employment rate is improved, shipyard industry productivity is increased, and national sovereignty in defense and safety is improved. These advantages are the positive impact of cabotage principle implementation. However, there are also negative impacts of the principle. The oil and gas mining activities can be disrupted when foreign transportation is forbidden, while national transportation is unready to serve the needs of these fields. Automatically, this situation will impact the Indonesian national economy. There is a potential for foreign exchange loss because the activities are performed by foreign companies instead of an Indonesian citizen.

Based on that, government support in the form of funding policy-making is highly anticipated by national shipping companies because the price of adequate ships is quite high, and the availability is still low, which makes it hard for domestic companies to obtain the required ships. In the world of service trading, Indonesia is a member of the World Trading Organization (WTO), which in principle, is embracing gradual liberalization to face the free trading era. Regulation on the cabotage principle is a part of the principle regulated in WTO/GATS regarding domestic regulation.

Because of that, the cabotage principle implementation is still in line with the service liberalization principle as regulated in WTO/GATS because WTO/GATS still recognizes the national sovereignty of its members. Moreover, Indonesia is yet to register its commitment as contained in the Schedule of Commitments (SOC) of sea transportation services. Cabotage principle implementation is expected to be able to form a system of independent and reliable Indonesian national shipping systems to welcome a limitless free trading era (Asnawi \& Iqbal, 2012).

The birth of the cabotage principle is propounded by the issuance of Presidential Instruction Number 5 the Year 2005 on National Shipping Industry Empowerment and Law Number 17 the Year 2008 on Shipping. Presidential Instruction Number 5 the Year 2005 emphasizes a consequent cabotage principle implementation and to formulate the required policies and steps according to their own authorities to empower the national shipping industry.

Cabotage principle consists of several points, which are; domestic shipping activities are conducted by national shipping companies; utilizing Indonesian flagged ships; manned by Indonesian citizen crew members; foreign ships are forbidden to transport passengers and/or goods to every island or every port in Indonesian water territory; foreign ships that are currently performing domestic sea transportation can conduct their activities for maximum three years after the issuance of this Law; every person that operates foreign ships to transport the passenger and/or goods to every island or port in Indonesian water territory is convicted with five years prison at maximum and a fine of $\mathrm{Rp}$ $600,000,000$ (six hundred million rupiahs) at maximum.

\subsection{Shipping Industry Empowerment According to Presidential Instruction Number 5 the Year} 2005

This policy is issued to optimize national shipping industry empowerment policy implementation by instructing related ministers such as the Minister of Finance and Industry, to implement a consequent 
Proceeding on International Conference of Science Management Art Research Technology (IC-SMART), Vol. 1 (1), 78-88

Indonesian Shipping Sustainable Development Law Approach Through Cabotage Principle Elfrida Ratnawati

cabotage principle and to formulate the required policies and steps according to their duties, functions, and authorities to empower national shipping industry. The content of Pensidential Instruction Number 5 the Year 2005 consists of six regulated aspects, which are commerce, finance, transportation, industry, energy and mineral resources, and education and training (BPKP, 2020).

4.4 The Impact of Strong, Compelling, and Principled Cabotage Principle for Indonesia At the early age of the implementation of this principle, there are several defiances from domestic shipping companies because most of the Indonesian shipping companies are joining a contract with foreign ship owners. By the issuance of this principle, domestic shipping companies are forced to sign a new contract with foreign ship owners. The other problem is that domestic companies are more interested in leasing foreign ships instead of owning their own ships because of high investment costs (Indonesia Maritime Blog Informations, 2019).

To buy a decent quality ship, domestic shipping companies have to provide billions on an investment fund. The amount is seen as highly burdensome by these companies. Another condition that makes it difficult for the government to implement the cabotage principle is the low number of Indonesian flagged ships owned by Indonesian companies, and the available ships are inadequate to fulfill domestic shipping needs. The condition of the available ships is also a problem. Almost all Indonesian flagged ships are used ships, old and unfit for cruising.

With tighter supervision from the government and compelling cabotage principle, the growth of the domestic shipping industry is improving and developing. This situation is evident with the growth of domestic shipping companies and Indonesian flagged ships owned by domestic companies. This increase is achieved because the domestic companies must meet several requirements to receive the operational permit, one of which is to have their own ships. Along with the increasing number of domestic ships, foreign ships are started to the left out from Indonesian water territory.

Domestic shipping companies, which were highly dependent on foreign companies, are starting to lose their dependencies. However, these dependencies are not entirely gone, and foreign companies are still influencing domestic companies, especially the ones that provide services for offshore activities. On offshore activities, domestic shipping companies are still using foreign ships on their activities. This decision is made because the price of ship is highly high if compared with another type of ship, and the activity requires high technological ships. With the existence of domestic companies that still utilizes foreign ships, the implementation of the cabotage principle is inhibited. The aim of the government to create domination of Indonesian ships in the domestic territory is delayed. That is why the government permits domestic shipping companies to utilize foreign ships for offshore activities until early 2016.

\subsection{The Development of Ship Number After Cabotage Principle Implementation}

For nine years of cabotage principle implementation, the growth of Indonesian flagged transportation armada experiences a significant increase over the years. From the data obtained, until 31 December 2013, the total number of Indonesian flagged ships is at 13,120 ships. If compared with March 2005 with 6,041 units of ships, it means that there is a significant increase of 7,079 ships or a $117 \%$ improvement. This significant increase is caused by the improved buying power of the shipping companies. However, the increase in ship number is not followed by the increase of offshore activities ships. The number of ships for offshore activities is still very low. From the obtained data, up until 2015, offshore activities require 253 armadas. With this weakness, the goal of the government to make Indonesian ships as the dominator in their own territory is inhibited.

The impact of cabotage principle implementation drives the development of the Indonesian shipping industry and allow more companies to involve in the industry. The positive effect of this situation is the formation of healthy competition in the Indonesian shipping industry, which also drives a healthy and competitive market situation in the industry. 
Proceeding on International Conference of Science Management Art Research Technology (IC-SMART), Vol. 1 (1), 78-88

Indonesian Shipping Sustainable Development Law Approach Through Cabotage Principle

Elfrida Ratnawati

The most dominant competition between these companies is the competition to earn a contract with goods producers that export or import their goods and needs. The ability to get a long-term contract is highly important for domestic shipping companies because, without these contracts, the companies wouldn't be able to optimize their operations. The long-term contracts provide job certainty for these domestic shipping companies.

4.6 The Supporting and Inhibiting Factors of Cabotage Principle Implementation

The supporting factor of the cabotage principle is the requirement of domestic shipping companies to develop their business so they would release themselves from dependency on foreign companies. The formation of the supervising team to identify ships is highly required so the implementation can be practiced effectively and efficiently. With this team, the ships operating in Indonesian waters are more controlled and supervised.

The government provides supports for domestic shipping companies by making it easier for them to obtain an operating permit and to receive information on the required ships. Banks and financial institutions are also helping domestic shipping companies by providing credits and fundings facilities. Supports from banks and financial institutions are important to help these companies fund ship procurements, which require relatively high investment.

\subsection{Inhibiting Factor}

There are several factors that inhibit cabotage principle implementation in Indonesia, which are; the inability of shipping companies to provide certain types of ships that would support offshore exploration and exploitation because the ships are very expensive. Besides that, the technological resource owned by Indonesian companies and the government is still very lacking. Also, the investment required to procure the ships is relatively high. To procure a decent quality ship, a company needs to prepare up to 20 billion rupiahs. With the level of investment, it is difficult for domestic shipping companies to procure any ships for their own companies.

The inexistence of long-term contract between goods producers and ship owners. Long-term contract is quite important for domestic shipping companies to optimize their operational capacities. However, the cooperation process is still in the forms of short-term contracts and creates several problems for domestic companies, especially on the job certainly aspect. The companies are prone to operational losses because there is no guarantee that a customer will use their ships.

The low human resource quality and quantity. Indonesian shipping crew quality and quantity is still at a low level and inhibits the implementation of the cabotage principle. With the increase of Indonesian flagged ships, the requirement of high-quality Indonesian crews to operate these ships are also increased.

\subsection{The Impact of Cabotage Principle Implementation}

There are several impacts of cabotage principle implementation on a country/government, which are categorized into positive and negative impacts.

1. Positive Impacts

The implementation of cabotage principle can enhance Indonesian sovereignty because more Indonesian ships are operating means that fewer foreign ships are sailing in Indonesian waters. This would create a stronger government and control foreign ships entering Indonesian water territory. The absorbance of domestic employees with the regulation to compel Indonesian flagged ship to be manned by Indonesian citizens and the increase of ship armada, this sector has been able to create more employment opportunities in Indonesian water territory. The situation has also enhanced the national security level because, with more Indonesian ships operating in Indonesian water, more people will be able to participate in securing Indonesian water territory from foreign ships that violate Indonesian water territory (Indonesia Maritime Blog Informations, 2019). 
Proceeding on International Conference of Science Management Art Research Technology (IC-SMART), Vol. 1 (1), 78-88

Indonesian Shipping Sustainable Development Law Approach Through Cabotage Principle

Elfrida Ratnawati

Besides guard Indonesian security and sovereignty, the implementation of the cabotage principle also provides a positive impact on Indonesian shipping companies by increasing domestic market share that only available for national shipping companies and Indonesian flagged ships and diminishes competition with foreign ships to improve domestic loading activities. Economy improvement and domestic loading increase are experienced by domestic shipping companies in the form of increased earnings. The payment or cost of the domestic crew is also lower than foreign crews because the quality of domestic crews is still lower than the quality of foreign crews (Aprilianto, Hakim, \& Hayat, 2014).

The implementation of the cabotage principle is also had a positive impact on Indonesian National Ship Owners Association or INSA. By the issuance of this principle, the member of INSA is increasing, which means that more shipping companies are formed. Indirectly, with more companies joining INSA as members, INSA will receive more operational earnings collected from these shipping companies, and more funds will be available to improve the national shipping industry and association. Domestic shipping companies are easier to be supervised as they join INSA as regulated in Presidential Instruction Number 5 the Year 2005 (Republika, 2018).

2. Negative Impact

The first negative impact is that there are not enough available Indonesian flagged ships for offshore exploration and exploitation that force the government to extend permits for foreign ships to operate in Indonesian water territory to early 2016. With this extension, the implementation of the cabotage principle is inhibited because there are still foreign ships operating in Indonesian water territory. The second negative impact is the existence of several companies that unwilling to submit to the cabotage principle (Asnawi \& Iqbal, 2012). There are a number of companies that refuse to submit to the cabotage principle because they feel that the implementation of this principle is troublesome for them. The lack of Indonesian flagged ships and high demand for available ships creates a situation where a lot of containers are stacked up in ports waiting for available ships. Besides that, the long route of transportation pushes the companies to take days to finish cruising; meanwhile, transportation demand keeps on increasing. The availability of funding from third parties, whether banks or nonbanks institutions, is very limited. The required cost to conduct ship procurement is very high, which sometimes also makes it difficult for third parties to provide funding, or demand the companies to wait for a long time until the fund is available (Hadi, 2019).

INSA or Indonesian National Ship Owners Association also feels the negative impact of cabotage principle implementation. INSA has never been involved in the policymaking process. Whereas INSA and its members are the most impacted parties of the implementation of the principle. There is yet an understanding between INSA and the government because of as an association, INSA will always put its members' interests before any others. If INSA feels that its members are unable to submit to government policies, INSA will refuse the policies. This situation is the basis of disagreement between INSA and the government (INSA, 2018)..

\section{CONCLUSION AND FURTHER RESEARCH}

The implementation of the cabotage principle in the Indonesian shipping industry still experiences various inhibitions, even though there are numbers of positive impact. The domestic shipping industry can be improved if the stakeholders can promote unity and can support each other. By doing so, the problems that might occur in the implementation of the cabotage principle can be resolved. For example, the availability of working contracts between domestic shipping companies and foreign companies as ship owners, the high amount of investment to procure ships, and the unreadiness of 
Proceeding on International Conference of Science Management Art Research Technology (IC-SMART), Vol. 1 (1), 78-88

Indonesian Shipping Sustainable Development Law Approach Through Cabotage Principle

Elfrida Ratnawati

domestic companies to operate shipping industry without foreign companies' involvement. All of these problems can be resolved.

The domestic shipping industry can be able to build a good and strong performance because of the implementation of the cabotage principle. This principle can compel and drive domestic shipping companies to be able to dominate the domestic shipping industry because this principle, apart from its various negative impacts, still possess numerous positive impacts that would be able to support the industry and create a developed shipping industry.

The government must be able to enhance cabotage principle performance by constantly issuing policies customized to the dynamics of needs. Updates and adaptation on circumstances that would support the domestic shipping industry to be able to be developed are highly required. The support and full trust of the government to form policies and to drive banking sectors and other types of funding institutions that would be able to support the industry from the monetary perspective is highly important.

\section{REFERENCES}

Aminata, J., \& Isdiana, F. (2019). Indonesian Export Analysis with APEC Members through Sea Transportation Mode. Diponegoro Journal of Economics, vol. 1, no. 1, Feb. 2019, https://ejournal2.undip.ac.id/index.php/dje/article/view/3802.

Aprilianto, R., Hakim, A., \& Hayat, i. (2014). The Implementation of Cabotage Principle in Indonesian Shipping Policy (A Study of Directorate General of Transportation and INSA), Jurnal Administrasi Publik, 758-764.

Asnawi, \& Iqbal, M. (2012, Juni 12). Implication of Cabotage Principle Implementation in National Shipping on Indonesian Shipping Companies Existence in WTO Framework Free Trading. Retrieved from Repository USU: http://repository.usu.ac.id/handle/123456789/34709, 2012-12-06

Biro Komunikasi dan Informasi Publik. (2016, Januari 12). Ministry of Transportation Provides an Exception for Foreign Ships to Conduct Offshore Activities. Retrieved from Direktorat Jenderal Perhubungan Laut: http://dephub.go.id/post/read/kemenhub-berikan-pengecualian-penggunaankapal-asing-untuk-kegiatan-lepas-pantai

Bonaparte, S. (2017, Februari 4). Cabotage Principle in Indonesian Marine Law. Retrieved from samuelbonaparte.com: https://samuelbonaparte.com

BPKP. (2020). Presidential Instruction Number 5 Year 2005. Retrieved from www.bpkp.go.id

CNBC Indonesia. (2018, Februari 13). 90\% of Export Loads are Dominated by Foreign Ships. Retrieved from CNBC Indonesia: https://www.cnbcindonesia.com/news/20180213101212-44198/90-muatan-ekspor-dikuasai-kapal-asing

Data Boks. (2017, Mei 12). How Many Shipping Armada Does Indonesia Possesses? Accessed on 20 June 2020. Retrieved from Kata Data: https://ataboks.katadata.co.id/datapublish/2017/05/12/berapa-armada-pelayaran-indonesia

Hadi. (2019, Januari 3). Indonesian Shipping Industry 2019. Retrieved from Maritim Indonesia: https://maritimindonesia.com/2019/01/03/industri-pelayaran-indonesia-2019/

Hasbullah, M. (2016). National Shipyard Strengthening Strategy to Improve National Domestic Shipping Armada Effectivity and Efficiency in 2030. Jurnal Riset Teknologi Kelautan, http://journal.unhas.ac.id/index.php/jrtk/article/view/693.

Indonesia Maritime Blog Informations. (2019, Mei 1). Cabotage Principle and Its Influence on National Trading Armada Development. Accessed on 4 September 2020. Retrieved from Indonesia Maritime Blog Informations: blog.docking.id 
Indonesia Maritime Blog Informations. (2019, Mei 1). Cabotage Principle and Its Influence on National Trading Armada. Retrieved from DOCKING.ID BLOG: http://blog.docking.id/asascabotage-dan-pengaruhnya-terhadap-perkembangan-armada-kapal-niaga-nasional/

INSA. (2018, Oktober 5). Cabotage Principle Must Be Maintained, Accessed on 5 June 2020. Retrieved from Insa.or.id: insa.or.id

Mahlisan, J. (2010). Analysis of Cabotage Principle Implementation on The Improvement of Competitiveness of National Classification Institution: A Case Study of Riau Islands Area, Volume 22, Nomor 12, Tahun. Indonesia: Balitbang Hub, Departemen Perhubungan Laut.

Nusantara Maritime News. (2015, Agustus 12). Cabotage Principle and National Marine Industry. Retrieved from Nusantara Maritime: http://www.maritimenews.id

Pangihutan, A., Thamrin, M., \& Suparman, A. (2016). The Quality of Shipping Agency Service Quality and International Communication on Shipping Companies. Jurnal Manajemen Transportasi \& Logistik Vol 3, No.2 (2016) DOI: http://dx.doi.org/10.25292/j.mtl.v3i2.102, https://journal.itltrisakti.ac.id/index.php/jmtranslog/article/view/102. Retrieved from https://journal.itltrisakti.ac.id/index.php/jmtranslog/article/view/102

Republika. (2018, Oktober 5). INSA Wishes That the Government Will Maintain Cabotage Principle, Accessed on 1 July 2020. Retrieved from Republika: Republika.co.id

Saputra, R. B. (2016). Implementation of Cabotage Principle in Indonesian Shipping Law. Retrieved from Thesis Universitas Airlangga: http://lib.unair.ac.id

Sofiyanti, N., \& Suartini, S. (2016). The Effect of Number of Fishing Vessels and Number of Fishermen on Fishery Production Results in Indonesia. Accounthink: Journal of Accounting and Finance Vol 1, No $01 \quad$ (2016) DOI: http://dx.doi.org/10.35706/acc.v1i01.442, https://journal.unsika.ac.id/index.php/accounthink/article/view/442.

Wijaya, A. (2019, Januari 22). Prospects for the national shipping industry in 2019. Retrieved from Antara News: https://www.antaranews.com/berita/790214/prospek-industri-pelayaran-nasionaldi-2019 